\title{
RELIGIOUS ADR: \\ Mediation in Islamic Family Law Tradition
}

\section{Ratno Lukito}

Syari'ah Faculty, State Islamic University Sunan Kalijaga, Yogyakarta

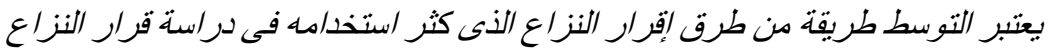

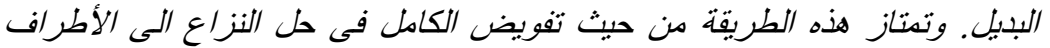

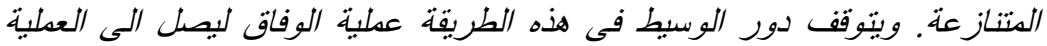

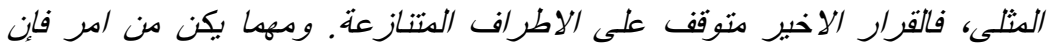

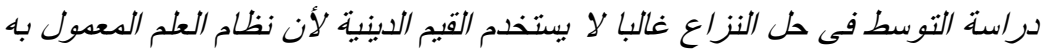

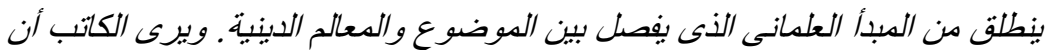

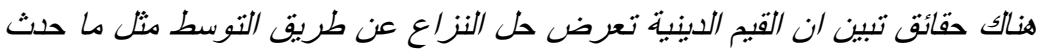

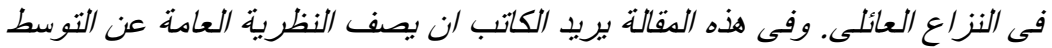

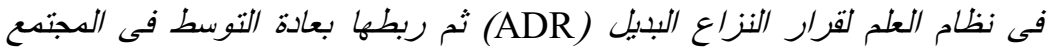

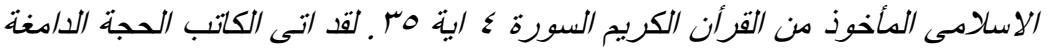

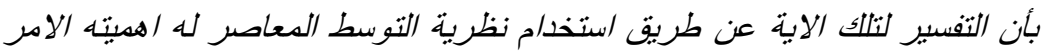
الذى يجعل تطبيق نظرية التوسط الاسلامى اكثر فعالية.

\section{Abstrak}

Mediasi adalah salah satu metode resolusi konflik yang banyak menjadi kajian dalam studi Alternative Dispute Resolution (ADR), atau Resolusi Konflik Alternatif). Kelebihan dari teori ini terletak pada metodenya yang sepenubnya menyerabkan proses resolusi tersebut kepada para pihak yang sedang konflik. Mediator dengan demikian sekedar memfasilitasi proses resolusi tersebut agar berjalan dengan baik. Keputusan akbir tetap berada pada para pibak yang berkonflik. Namun begitu, selama ini kajian mengenai mediasi ini tidak pernah melibatkan nilai- 
nilai agama. Sistem ilmu mengenai hal ini lahir dari masyarakat sekuler sebingga dilihat sebagai subjek yang terpisah dari kajian agama. Penulis berpendapat babwa sejatinya banyak nilai-nilai yang sudab ditawarkan oleh agama terkait mediasi ini. Islam sebagai contob telah menawarkan metode mediasi sebagai salah satu sarana dalam pencapaian perdamaian, khususnya dalam hal konflik keluarga. Dalam tulisan ini penulis mendespkripikan tentang teori umum mediasi dalam sistem keilmuan ADR dan kemudian menghubungkannya dengan tradisi mediasi dalam masyarakat Islam yang diambil dari Qur'an IV:35. Dalam argumentasinya penulis mengemukakan babwa interpretasi terhadap ayat tersebut dengan menggunakan teori-teori mediasi moderen sangat penting untuk dilakukan, sehingga implementasi teori mediasi Islam dapat lebih ditingkatkan efektifitasnya.

Keywords: ADR, mediation, dispute, family law

\section{A. Introduction}

Mediation is in essence a dispute resolution process wherein a neutral figure, the mediator, helps parties communicate with each other, brainstorm a problem, and negotiate their own settlement to their dispute. With its informal character, mediation can be said as one way to solve conflicts by turning the problem over to the concerned parties, and not to another individual. It is the character that convinces many of the usefulness of mediation as an effective way to resolve a conflict without inviting other problems.

Much has been written on the topic of mediation, but mostly on such issues as how to achieve more effective mediation, who is qualified to be a mediator, and on outcome measurement. ${ }^{1}$ In reading the vast literature generated by these debates, however, it appears that researchers have ignored religious teachings as basic sources for the process. I believe that a general theory based on a particular set of religious values has not been developed because the debate over the mediation process and outcome has never considered religion as a basis

${ }^{1}$ Douglas E. Noll, “A Theory of Mediation”, Dispute Resolution Journal, 2001, p. 
for this conflict resolution method. Religion is seen as a totally separate world from the debates. I propose here that when a religious aspect is introduced into the conflict resolution method, mediation process can be more effective.

In this paper attention will be focused on Islamic teachings with respect to mediation. The discussion will focus upon mediation as one method in family disputes resolution, a method actually suggested in the Qur'an, the primary source of Islamic legal tradition. Both the process and outcome of the Islamic mediation method will be the main topics discussed in the paper. In the first stage of the discussion, a general theory of mediation will be offered as an introduction to understand its common features as a method of dispute resolution. Such a theoretical view of mediation is also useful as a comparative tool for understanding the theory of mediation in Islamic family law. The challenge posed to certain practical aspects of Islamic mediation will also be discussed later in reference to the growing tendency towards mediation/arbitration hybrid as its approach.

\section{B. General Theory of Mediation}

Mediation can be defined as a voluntary process in which disputing parties negotiate their own settlement with the help of an impartial mediator. ${ }^{2}$ In this process the negotiating parties decide the outcome, while the mediator facilitates the process. With this understanding, the mediation is therefore to be differentiated from arbitration. Though both mediation and arbitration methods benefit from a third party other than the disputing parties in coming to a settlement outside of court, mediation is very unique in terms of the involvement of the neutral party. For whereas in the arbitration process the neutral is to decide a dispute based on its merit, the neutral's role in the mediation is merely that of a facilitator enabling both the parties

${ }^{2} \mathrm{~A}$ common encountered definition of mediation can be found in Jay Folberg and Alison Taylor, Mediation: A Comprehensive Guide to Resolving Conflicts Without Litigation (San Francisco: Jossey-Bass, 1984), p. 7. It reads as follows: "Mediation is the process by which participants, together with the assistance of a neutral person or persons, systematically isolate disputed issues in order to develop options, consider alternatives, and reach a consensual settlement that will accommodate their needs." 
to come to a settlement. It is the disputing parties who decide and create the resolution of their conflict. ${ }^{3}$

The character of the informal legal solution in mediation is such that the conflict's resolution is not in the hands of the third party but is returned to the actual parties to the conflict. This may be the reason why, in the last few decades, mediation seems to have become one of the most favorite dispute resolution methods. The more that the alternative dispute resolution (ADR) process is used in dealing with some kinds of conflicts outside the formal judicial process, ${ }^{4}$ the more people are beginning to see mediation as one of the most effective such methods..$^{5}$ Many now believe that mediation is in fact the kernel of the ADR. Akin to the general principles of the ADR, mediation can offer more flexibility, privacy and participation for all the parties in finding solutions other than those offered through the adversarial system.

As far as the technical process of mediation is concerned, it can be said that it is, in essence, a social interactive process in which a neutral, impartial third party facilitates the interaction between conflicting parties with the goal of helping the participants to develop their own agreement resolving the disputed issues between them. The social interactive process between the disputing parties is therefore the most fundamental aspect in mediation since it is within this interactive process that mediation can be developed. The presence of the third party is not intended to interrupt the dyadic communication established in the mediation, though it certainly has an impact on the pattern of the relation between the two actors due to the communicative interaction between the mediator and the parties. ${ }^{6}$ The

${ }^{3}$ John W. Friess, The Source of Power of Mediators in the Resolution of Conflict (Master Thesis, University of Wisconsin, 1986), pp. 2-5.

${ }^{4}$ See James L. Creighton, "A Tutorial: Acting as a Conflict Conciliator", Environmental Professional, 1980, p. 119.

${ }^{5}$ See for example Andrew J. Pirie, Alternative Dispute Resolution, Skills, Science, and the Law (Toronto: Irwin Law, 2000), p. 148.

${ }^{6}$ Eva Robins and Tia S. Deenenberg, A Guide for Labor Mediators (Honolulu, Hawaii: University of Hawaii, 1976), p. 4. 
dyadic communicative pattern between the two parties is changed by the presence of the third party, the mediator.

In his/her capacity as a mediator, the third party should be impartial and neutral. He/she is usually unknown to the disputing parties prior to the initiation of the mediation process. Therefore, the presence of the mediator in the conflict should be based on the selection and approval of both parties. What this usually means is that the mediator is an "outsider" to the conflict and not a participant in the dispute. ${ }^{7}$ Being an "outsider" means the mediator has no right to be involved in the conflict or its outcome. In this regard, at least in "pure" mediation, the mediator has no resources that are pertinent to the conflict or that enter into the discussions and negotiations. ${ }^{8}$ And to maintain equality between the parties, the mediator has very few, if any, ties of social control to the parties, and very little authority over them.

Given the last point in particular, it is clear that the mediator functions primarily as a facilitator. No decision in the negotiation process is under the control of the mediator. ${ }^{9}$ In contrast to adjudication and arbitration wherein the third party usually imposes a final and binding decision, in mediation, the mediator does not have, nor is expected to have, powers to resolve the dispute. What the mediator is concerned with is, therefore, not the content of the dispute but merely the process of conflict resolution. ${ }^{10}$ How the interaction of the parties can be made to function optimally in order to advance the process, as well as how specific resolutions can be achieved to help to generate a settlement, are the questions a mediator is most preoccupied with. ${ }^{11}$

${ }^{7}$ Ronald J. Fisher, "Third Party Consultation: A Method for the Study and Resolution of Conflict", Journal of Conflict Resolution, 1972, p. 77.

${ }^{8}$ Carl. M. Stevens, "Mediation and the Role of the Neutral" in John T. Dunlop and Neil W. Chamberlain, eds., Frontiers of Collective Bargaining (New York: Harper \& Row, 1967), p. 271, 281.

'Fisher, "Third Party Consultation".

${ }^{10}$ Jean M. Bartunek, Alan A. Benton, and Christopher B. Keys, “Third Party Intervention and Bargaining Behavior of Group Representatives", Journal of Conflict Resolution, 1975, p. 533.

${ }^{11} J a m e s$ L. Creighton, “A Tutorial: Acting as a Conflict Conciliator”, Environmental Professional, 1980, pp. 125-6. 
As the mediator is only concerned with the process, he/she is then allowed to observe carefully the interchanges between the parties, something that the parties in conflict are unable to do because of their close involvement with the conflict. ${ }^{12}$

Concerning the role of the mediator, the most important function that should be borne in mind is the mediator's responsibility to create an atmosphere where all the disputing parties are able to express their respective positions and to encourage them to move towards resolution. ${ }^{13}$ Although mediators may come to the process with certain kinds of ideas about the goals of mediation, they must never impose any construct on the parties. They may introduce their ideas to the parties at the opening session of the mediation with the understanding that the disputing parties are the ones who will decide whether to adopt the ideas or not as the mediation process is under the control of the parties.

Theoretically, mediators are guided by one of three approaches to mediation. The first is a settlement approach, in which the mediator's primary concern is to define a zone of settlement and to guide the parties to a resolution that falls within a particular settlement zone. Since the goal of the mediator is the settlement itself, he/she is not concerned with other questions, such as whether the relationship of the parties involved is maintained after the mediation ends, or whether the parties successfully leave the process with a positive outcome. The second is a problem-solving approach, used when the mediator believes that the mediation should lead to a better position for the parties than was the case at the outset of the mediation. In this situation, the problem-solving mediator can, for instance, suggest the parties that they find a way of "expanding the pie" rather than merely "splitting it." The third approach, on the other hand, is more ambitious than the previous two, and is what is commonly called transformative mediation. In this approach, the mediator is expected to lead the parties to a form of "moral growth" in some fundamental sense. With this

\footnotetext{
${ }^{12}$ See J. W. Burton, Conflict and Communication: The Use of Controlled Communication in International Relations (London: MacMillan, 1969).

${ }^{13}$ D. G. Pruitt, Negotiation Behavior (New York: Academic, 1981), p. 204.
} 
kind of mediation, the mediator can help the parties to foster a better relationship between them so they can make a model that can be used to resolve any further conflict that may arise in the future. Regardless, however, of what theory of mediation he/she may espouse, the mediator must still preserve neutrality. This is a crucial matter for the mediator, so as to ensure that all the parties will perceive the resolution as fair. ${ }^{14}$

Thus it is in the mediator's responsibility to drive the interaction process between the parties towards a resolution of the issues. ${ }^{15}$ As his/her concern with the communicative patterns of the parties engenders the successfulness of the mediation, the mediator should be able to control the interaction of the parties so as to reduce any "unhealthy" communicative exchanges and move them towards more productive exchanges. In this case, the role of the mediator is more that of an initiator to problem-solving activities in which the conflicting parties can change their focus from a hatred-energy-driven encounter to a more problem-oriented relation. ${ }^{16}$ During these activities, the mediator facilitates and referees the process and discussions in an attempt to assist the parties in developing an agreement.

It can be said therefore that the primary goal of the mediation process is an agreement reached by both parties. In making an agreement, the parties can chose from a number of forms. Sometimes they can make the agreement in the form of a legal contract, approved and ordered by a court of law, or their agreement can also be instituted by the parties themselves without the court's intervention. ${ }^{17}$ No matter what the form of the agreement, it is the agreement itself that the mediator should always concentrate on in his assistance to the participants. In the process of reaching an agreement, certain other aspects related to the dispute such as the participants' communicative patterns, relational conflict, conflict resolution techniques, etc., are

\footnotetext{
${ }^{14}$ Randall L. Erickson, "Presentation: Mediation of an Illegal Dumping Case," Annual Partnership Conference, August 21-23, 2001), online: Canadian Integrated Waste Management Board http:/ / www.ciwmb.ca.gov.

${ }^{15}$ Pruitt, Negotiation Behavior, p. 206-7.

${ }^{16}$ Pruitt, Negotiation Behavior, p. 204.

${ }^{17}$ Friess, The Source of Power, p. 24.
} 
sometimes also affected. Yet, those aspects are not the main concern in mediation. This what makes mediation dissimilar to such other thirdparty processes as counseling or therapy since the last two methods focus more on the relationship itself or the solving of relationship problems. ${ }^{18}$ In other words, in contrast to those other processes that are primarily relationship or person-oriented, mediation is more issueoriented. Mediation is therefore a special forum wherein the parties in conflict can freely develop a plan that will end their dispute cooperatively. Any spin-offs of the conflict resolution process engaged by the mediator, such as changes in beliefs, values or the relationship between the parties, are not to shift the core mission of the mediation.

\section{Mediation in Islamic Family Disputes}

In Islamic legal tradition, mediation is recognized as one resolution method for family disputes, especially in dealing with conflicts between husbands and wives. This kind of outside-court resolution, however, is not understandable without comprehending the basic teaching of the Islamic law of divorce. The Islamic regulations on this matter are, taken as a whole, unique, given the fact that although divorce is not forbidden, it falls within the legal category of "reprehensible." One report from the Prophet describes divorce as a permissible yet abhorrent thing. ${ }^{19}$

Here we see the inclination of modern Muslim jurists (especially) to regard divorce as a kind of emergency door used only when the husband-wife conflict is irreconcilable. Therefore, they view divorce as far from the best solution in a family dispute as long as another way is still possible to resolve the problem. Differently put, in family disputes divorce is not the only remedy, and as long as other means of resolving the problem are available, the union between husband and wife in family bond should not be dissolved.

${ }^{18}$ Jay Folberg and Alison Taylor, Mediation: A Comprehensive Guide, pp. 7-8.

${ }^{19}$ See the Hadith reporting the Prophet as saying: "Abghad al-ḥalāl ilā Allāh alTalāq" in Abū Dāwud Sulaymān ibn al-Ash'āt al-Sijistānì al-Azdi, Sunan Abi Dāwud, Vol. II (Beirut: Al-Maktab Al-'Așiyah, 1980), pp. 254-5; and Muhammad ibn Yazid alQazwaynì Ibn Mājah, Sunan Ibn Mājah, Vol. I (Cairo: 'Isā al-Bāby al-Halāby wa-Shirkah, 1952), p. 650. 
Mediation therefore has a very important role in Islamic family dispute resolution. In keeping with the Islamic teaching on divorce circumvention, mediation can be seen as a primary avenue of dispute resolution allowing the parties to avoid the more serious consequence of the juridical process. The importance of mediation in family dispute can be seen from the fact that the Qur'an itself gives a detailed injunction concerning the mediation process in such disputes in verse 4:35, which can be translated as follows:

And if you have reason to fear that a breach might occur between a (married) couple, appoint an arbiter from among his people and an arbiter from among her people; if they both want to set things aright, God may bring about their reconciliation. Behold God is indeed allknowing, aware. ${ }^{20}$

The above verse clearly sets forth a procedure to be followed in mediating cases of conflict between husband and wife. In any marital dispute each party should appoint its own representative (the verse uses the term "arbiter" or hakam in Arabic), selected from their respective families, to negotiate a solution to the conflict. The actual method of mediation described in the verse is therefore quite distinct from the common understanding of the mediation process. The different aspects of the Islamic mediation process may be summarized under three headings: first, the third parties selected for mediating the dispute should be taken from the relatives of the husband and wife. Second, the representatives act as pro-active mediators in the sense that they are involved actively in the process of making a settlement. And third, in view of the third parties' involvement, they have more of an insider role in the process of negotiation. The mediation in this case therefore refers to a process in which conflicting spouses attempt to reach a consensual settlement of issues in dispute with the assistance of persons coming from the families of both parties.

${ }^{20}$ Muhammad Asad, The Message of the Qur'an (Gibraltar: Dar Al-Andalus, 1980), p. 110. Compare to Abdullah Yusuf Ali, The Holy Qur'an: Text, Translation and Commentary, as follows: "If ye fear a breach between them twain, appoint (two) arbiters, one from his family, and the other from hers; If they wish for peace, God will cause their reconciliation for God hath full knowledge, and is acquainted with all things." 
The verse, therefore, proposes a unique mediation method for a family disputes. In terms of the process, it is substantially different from the common understanding of mediation. For whereas in Islamic mediation the persons serving as mediators must come from the relatives of both parties, common mediation recommends that mediator be one an outsider. It would be even better if the mediator is someone to whom the parties have no relationship whatsoever. This is seen as a guarantee that the mediator can referee the conflict impartially.

The Islamic practice of involving the participants' relatives to mediate a family conflict seems to be justified by the idea that the dispute between husband and wife is in fact inseparable from the social values of Muslim society. Here, the common institution of the extended family affects the way of seeing family disputes. In such a type of family, the familial bond includes not only husband, wife and children, but also grandmother, grandfather, uncle, niece, etc. Although they do not necessarily live together in one place, they still usually share the problems of daily life among family members. Any conflict between the elements of an extended family is therefore seen not as an individual but a family problem with the consequence that its resolution is crucial to all members of the unit.

Understanding such social values is important if we want to grasp the philosophical ideas of family dispute resolution in Islamic law. Indeed, the social values of a communal way of living, reflected in the extended family, inevitably influence the method of conflict resolution in disputes between husband and wife. As marriage means also the union between the two families of bride and groom, any dispute that might arise from the marriage will not be viewed as a detached issue but rather as a problem that all members of both families have to cooperate to resolve. It is for this reason that the role of mediator in Islamic family disputes falls to persons who still have a relationship with the family of each of the disputing parties - usually the husband and wife. The selection of a mediator who is also an insider in this process is thus not intended to gain an unfair advantage but more as a way to get an effective resolution of the conflict without neglecting the social values of society in general. 
Social values also account for the contrast in the sociological foundations of the two types of mediation. It can be said that common mediation is more developed in societies where the nuclear family is the norm and where disputes are seen as something owned individually by the concerned family, and not extended to parties outside the core members of the family - the husband and wife. Hence, efforts at resolving the conflict are focused on the parties who are immediately concerned with the problem. At the same time, the third party is no more than a facilitator, enhancing the communicative relations between husband and wife and not the content of the negotiation.

Islamic mediation, on the other hand, seems to view the mediator in a family dispute as an active agent in the mediation process. He/she will be intimately involved in the process of finding a solution to the conflict so long as the husband and wife involved agree to his/her presence. Of course, since in the initial process of the mediation, both parties are responsible for selecting their side's mediator, they must choose someone from their family circle who has integrity, honesty and sense of justice in dealing with their conflict. In most such cases we find that the mediators are usually older men or older women believed to have the ability to negotiate with their counterpart so as to arrive at a resolution.

The mediators in Islamic tradition are therefore key to the success of the mediation. Their very active involvement in the process permits them to plunge into the content of the conflict and not fell restricted to facilitating the process, as is the case with mediators in other approaches. This means that in Islamic mediation the mediator will act not merely as a facilitator but more as negotiator of the conflict resolution. As a negotiator, each mediator is then free to discuss, bargain and offer any options to his/her counterpart in order to make the voice of the represented party heard. His/her main duty in this process is to compare the arguments of both parties, discuss these latter and negotiate all possibilities to arrive at a settlement of the dispute. This is because as an insider with respect to both parties, the mediator is usually very well acquainted with the situation and condition of the party he/she represents. Therefore, it is expected that, because of this 
advantage, the negotiation process with the other party will run all the move smoothly.

The position of mediators as negotiators for the parties seems contingent on their status as insiders in the very process of mediation. They are not seen as outsiders since, in the process of trying to reach an agreement, both the interested parties to some extent even rely on the mediators' role in negotiating the solution. It happens that in many cases both parties allow themselves to be guided by the mediators. Given this enhanced role, the mediator in Islamic tradition has therefore a broader spectrum than that of the mediator in the common process. In conjunction with their role as negotiator, the Islamic mediator is deemed to be able to undertake the mediation process in a wider perspective, not only to dig at the roots of the conflict, but also to find a solution to the problem. The approach that the mediator needs to take in mediating between the parties is therefore not only to create " $\mathrm{a}$ settlement zone" of the conflict without regarding the following relationship of husband and wife after the mediation process. His/her responsibility is also to include making every effort to improve the relationship between the husband and wife and to make them understand each other's position so that they are capable of improving their "moral deposit" to face the future. In other words, the mediator is not only to help the parties settling the problem but also to educate them to have an independent moral capability to solve their own problems whenever these may arise in the future.

In short, mediation in Islamic family disputes cannot be described solely as an issue-oriented process, since it also concerns itself with how to develop a better relationship between both parties so as to avoid eventual dissolution of their marital relationship. This is in line with the idea that mediation in Islamic tradition is in essence an ongoing process that aims at fostering a healthier family life. Here we see the profoundly informal character of this Islamic way of mediation. Conflict between husband and wife is, as much as possible, to be settled within the circle of the family, without interference by an outsider in the role of neutral party. Hypothetically, this informal process of mediation is vital to settling family disputes before divorce proceedings 
are set in motion, and the judge's decision -so final and unpredictableis rendered.

\section{The Challenge of Practice: Mediation/Arbitration Hybrid}

Considering the huge role of the mediator in the Islamic form of the process, it is clear why the Qur'anic verse above uses the term "arbiter" (hakam) ${ }^{21}$ to identify the mediator. By using such a term, the verse seems to describe the conflict resolution process in family disputes as arbitration and not mediation. In my opinion, however, the use of arbitral language in the verse is not to mean indicating that the dispute resolution approach instigated in the Qur'an is purely an arbitration process. This is due to the fact that, according to the verse, both husband and wife retain the right to decide the final outcome of the resolution process. This interpretation is justified by the words "if they both want to set things aright, God may bring about their reconciliation (wa in yuridà islăḥan yuwaffiqillāhu baynabumā)."22 This sentence serves to confirm that, although the mediators can be deeply involved in the content of the negotiations, the reconciliation as the primary outcome of the process is not theirs to decide as they are at most concerned with the process of encountering the voice of the participants. The character of the mediation process is therefore made more apparent in the verse as it still assigns the right to make the final decision to the

${ }^{21}$ The Arabic word hakam comes from the root $\not-k-m$, which is to be of nonArabic origin, has in fact a number of meaning. The principal meaning of its simple verb is "to govern", "to restrain", "to pass judgment", and "to be sage". The word hakam appears twice in the Qur'an, i.e., in 4:35 (the verse above) and 6:114. See this explanation in Jane Dammen McAuliffe, Encyclopaedia of the Qur'an (Leiden: Brill, 2001), p. 147; On the word hakam meaning arbitrator in relation to the verse 4:35 see 'Abd al-Rauf Al-Mișri, Mu'jam al-Qur'an (Cairo: Maṭa'ah Hijazi, 1948), p. 191; also John Yahya Cason, Kamal El-Fadl and Fredrick Fareed, An Exhaustive Concordance of the Meaning of Qur'an (Baltimore, Md.: Islamic African Relief Agency, Eastern Regional Office, 2000), p. 64.

${ }^{22}$ The majority seems, however, to interpret that the verse is more arbitral in its approach as etymologically the term hakam employed in the verse means arbiter. And the preposition in the verb yurida of the sentence wa in yurida is ishanan is referred to the two arbiters and not the two husband and wife since the first is the closest in its reference. See also note 20 . 
husband and wife. In other words, whatever the involvement of the mediators in finding a way to resolve the conflict, the final outcome of the process is still in the husband's and wife's hands to decide.

Another possible way to interpret the above verse is that mediation in Islamic family disputes can be understood as a combined process in which the mediator's role is not only to facilitate discussion by the parties, as in common mediation, but also to play other roles such as negotiator, problem-solver, guide, and perhaps also arbitrator. This is in part based on what a mediator actually does in the Islamic mediation process, as has been described above. If so, the verse may be understood as simply a general expression of the divine will regarding conflict resolution within the family, where the technical aspects of the resolution process are left undefined. Further development of the process is therefore to be undertaken by the society in conjunction with the development of the culture of dispute resolution itself. In line with this idea, the modern-day development of alternative dispute resolution (ADR), in which the idea of combining mediation with arbitration is its most current phenomenon, might therefore as an approach to understanding the dispute resolution feature set forth in the verse.

Nowadays, developments in the practice of ADR seem to be influenced by the idea of how to develop a certain way of dispute resolution which can improve the effectiveness of the method in reaching a settlement. One answer is the increasing popular idea of combining mediation with arbitration. A hybrid version of the mediation and arbitration processes has not yet been fully realized, as the idea is still in the process of development. Yet, this reflects current developments in most countries with long experience in the use of ADR. As an example, the recent survey conducted by the Cornell University/PERC Institute on Conflict Resolution and Price Waterhouse on the use of alternative dispute resolution (ADR) among one thousand of the largest U.S. corporations shows that mediation is becoming more popular than arbitration. The survey also finds that inhouse lawyers complain about arbitration's lack of judicialization, while those in the business community generally see mediation as more effective due to its attention to the role of the parties in the process of 
resolution. ${ }^{23}$ With the growth in the use of mediation throughout the industrialist countries like United States, Canada, United Kingdom, Australia and New Zealand, mediation seems to have entered its heyday. More observers of ADR can point to a brighter future for mediation in the process of resolution.

The fact that more people see mediation as more promising in the dispute resolution process seems beyond question. Yet, the question remains: What in fact is the reason for this inclination? Is it because of the merits of mediation or the defects of arbitration? The answer depends on a fair evaluation of the strengths and weaknesses of the two methods. Recent consumers of arbitral services have complained about the increasingly adversarial character in arbitration. This is what has been commonly called the judicialization of the arbitral process, the thing that seems causing dissatisfaction of most customers. The current practice of arbitration seems to neglect the merits of arbitration that originally inspired the process. What were originally seen as the main reason for customers to choose arbitration, such as simplicity, clarity, speed and economy, are now being overlooked, and instead arbitrators now emphasize the more jurisdictional, legalistic and formal aspects of their work. Some respondents also suggest that the practice of arbitration is too expensive, time-consuming and disruptive to the business relationship. By contrast, consumers of mediation are expressing their satisfaction, since mediation is seen by them as a process in which both parties can obtain a positive solution due to its continuous control of the parties, speed, confidentiality, lower legal costs, more effective time management and the retention of the business relationship. A relevant characteristic of mediation is the absence of any obligation to apply the law strictly so that a speedy resolution, simple procedure and low costs can be obtained. Another important benefit of mediated settlements is that they are confidential, and do not appear in either court records or in the press. ${ }^{24}$

\footnotetext{
${ }^{23}$ Francesco Anchini, “'Concitration': The Ultimate Example of ADR”, World Arbitration \& Mediation Report, 2002, p. 162.

${ }^{24}$ Robert Coulson, "Wipo Publication n 728(E)” p. 22.
} 
The above factors seem to account for why people are tending to opt for the mediation process as the solution to their conflicts rather than for arbitration. However, the benefits of mediation should not lead observers to ignore its disadvantages. The most pertinent of the latter is that mediation depends heavily on the parties' willingness to reach a solution. To make matters worse, mediation does not usually lead to an enforceable decision. ${ }^{25}$ This is due in part to the less judicial character of mediation. Indeed, up to now there has been no international convention for the enforcement of mediated settlements. ${ }^{26}$ This makes it especially awkward to use mediation when the parties in dispute are from different countries or legal jurisdiction.

Having said this, it is important to understand the new trend among ADR proponents to introduce a combination of mediation and arbitration in the resolution process. Although most cases involving this new strategy usually deal with international business law, the idea of combining a mediation and arbitration process can also be used in family or domestic cases. It is in this sense that verse 4:35 can in fact be interpreted as a general injunction of the Qur'an for Muslims to create an effective dispute resolution (especially in family cases) in such a way that mediation/arbitration hybrid is possible. In my opinion, this is also an answer to the question why the Qur'an speaks of arbitral involvement in cases of family mediation. The verse seems therefore to support the idea of combining the mediation and arbitration processes in resolving family disputes. Differently put, the hybrid process of mediation and arbitration is not seen as transgressing the spirit of the verse as long as it can ensure the attainment of the main purpose of the conflict resolution process commanded by the Qur'an, namely the settlement of the family dispute.

Theoretically, the idea of mediation/arbitration combination is basically grounded in the need to improve the effectiveness of the third party involvement in the process of reaching a settlement of a

${ }^{25}$ Anchini, “Concitration': The Ultimate Example”, p. 163.

${ }^{26}$ Richard W. Page-Page \& Busch-San Diego-Cal. USA-, "The Institutional Response to Changing Needs of Users", Paper, presented to the Biennal Conference of the International Federation of Commercial Arbitration Institutions (IFCAI), hosted by the WIPO in Geneva October 24, 1997, p. 102. 
conflict. A kind of mixing-process between mediation and arbitration is thus used here as its approach. At a practical level, some arbitration institutions have now introduced mediation into their former arbitral system. They have proceeded by integrating mediation into the body of the arbitration process using two approaches. First, a separation approach is used by adding a new separate set of rules for mediation in a pre-existing body of arbitration rules. In this criterion, some cases require that mediation remedies are inserted prior to proceeding to arbitration. While, second, merger approach is used when the two processes of mediation and arbitration are combined into one form. As a result of combining the two features, a simpler arbitral process yet a more complex mediation process is applied in the disputes encountered. $^{27}$

The prevailing form of this hybrid involves submitting to mediation in the initial step of the dispute resolution process and, should the conciliation attempts fail, instituting an arbitration process. The emergence of this novel strategy is now commonly found in many countries, not only in the developed countries where ADR has long been practiced but also in some countries in Asia where it is less well known, such as China (including Hong Kong), Singapore, Sri Lanka and India. This trend is also followed in some non-common law jurisdictions in Asia, where regulations are provided that allow the mediator to act as arbitrator in the same dispute with the parties' consent if any efforts at mediation are found to be unsuccessful. ${ }^{28}$ In China, attempts have even successfully combined the Western approach of arbitration with Chinese-style of conciliation. ${ }^{29}$ The same principle is also observed in some other Asian countries like Korea, Japan and Vietnam. The basic idea is that the two features of mediation and arbitration can be applied together to supplement the attempts of reconciliation. This is not impossible as long as the strengths of the two methods can be combined to make up for their respective weaknesses.

${ }^{27}$ Ibid.; Anchini, “"Concitration': The Ultimate Example”, p. 163.

${ }^{28}$ P.G. Lim, “Wipo Publication n. 759(E)”, p. 123.

${ }^{29} \mathrm{Ibid}$. 
The hybrid idea of mediation and arbitration can, on a practical level, be used to approach the model of conflict resolution process spoken of in the Qur'anic verse cited earlier. From the verse, we can grasp the proposition that as long as the husband and wife are still willing to find a resolution to their conflict -having ruled out divorce as an option-, the mediators they send to negotiate the resolution can approach the process in such a hybrid way. Using a combination of mediation and arbitration as their approach, the mediators from both the husband's and wife's sides can thus work together to resolve the dispute between the parties. To do so they will adopt one of three possible strategies: first, by mediating between the parties at the initial stage, and when the conciliation approach fails, proceeding to an arbitral approach. Second, mediation can be inserted into an ongoing arbitration process, especially when the two parties seem dissatisfied with the arbitral proceedings. And third, mediation can take place upon the request of both parties after arbitration has been unsuccessful, leaving open the possibility that, should this approach then fail, arbitration proceedings will resume. These tactics should still be based on the ideology of party autonomy in the sense that the parties (husband and wife) should be the ones whose agreement will be the basic starting point of the dispute resolution strategy. Thus, whatever model of the hybrid is decided upon in the process of making a settlement, it should always depend upon the parties' agreement.

As the Islamic dispute resolution process carried out in situations of family conflict is intended as an informal process aimed at circumventing dissolution of marriage, the outcome of the process is basically directed at instilling a healthier relationship between both husband and wife as a "moral capital" for continuing their marriage. In this case, the agreement of the parties must therefore be the basis of all attempts made by the third party in pursuing the dispute resolution process. This means that, as Qur'anic verse insists, the success of the process ultimately depends on the intentions of the conflicting parties. If they want deliberately to resolve the dispute, then the resolution process will be successful, whatever the format of the mediation. Yet, if the parties want no resolution to their conflict, the conflict resolution method developed in the process will not work effectively. The final 
outcome of the process is therefore in the hands of the parties to decide. Here, both mediation and the mediation/arbitration hybrid are used merely as an attempt to help the process of resolution to work effectively in settling the dispute.

\section{E. Conclusion}

From the above explanation, it seems as though marital dispute resolution elucidated in the Qur'an 4:35 can be understood in the light of the modern method of ADR. This is possible if the verse is viewed as a general proposition, which needs human interpretation to apply the verse in line with the modern culture of dispute resolution. Here, mediation and the hybrid of mediation and arbitration processes can be used in applying the family dispute resolution mechanism formulated in the verse.

The use of the modern method of ADR to approach the Qur'anic family dispute resolution can be justified without neglecting the main purpose of the basic Qur'anic teaching, namely, the circumvention of marital dissolution in family disputes. The effectiveness of the methods used in this dispute resolution process is therefore dependent on its success in settling the conflict, since the divorce of a husband and wife is deemed undesirable from the start. Though the final resolution is in the hands of the couple to decide, the mediators are required to make every effort possible to reconcile the parties. Viewed in this way, the mediator can play the role not only of a mere facilitator, but that of a negotiator, advisor and even arbitrator. This combining of roles is aimed at finding any way possible to settle the dispute.

Interpreting the above Qur'anic verse in such a way that its meaning comes closer to the modern culture of dispute resolution will not be successful if the divine values embedded in the verse are isolated from the cultural values of the human-created ADR. The message of the verse will not even be understandable if we neglect the cultural background within which these divine values were expressed. Here, the religious injunction of conflict resolution is not seen as a separate entity, incommensurable with human-created dispute resolution methods. Moreover, the application of this religious conflict resolution can in fact be combined with modern trends in the practice of ADR in 
Ratno Lukito

order to attain the main purpose of the verse, namely, the settlement of disputes between parties outside of the legal system. In so doing, the conflict resolution feature set forth in the Qur'an cannot be grasped as something beyond the development of human thinking on ADR. Therefore, at a practical level, the application of the verse cannot be seen as rigid; indeed, it is flexible and susceptible to the development of alternative dispute resolution methods. 


\section{BIBLIOGRAPHY}

Anchini, Francesco, “'Concitration': The Ultimate Example of ADR”, World Arbitration \& Mediation Report, 2002.

Asad, Muhammad, The Message of the Qur'an, Gibraltar: Dar Al-Andalus, 1980.

Ali, Abdullah Yusuf, The Holy Qur'an: Text, Translation and Commentary, Lahore: Shaikh Muhammad Ashraf Kashmiri Bazar, n.d.

Azdi, Abū Dāwud Sulaymān ibn al-Ash`āt al-Sijistānī al-, Sunan Abi Dāwnd, Vol. II, Beirut: Al-Maktab Al-'Asiyah, 1980.

Bartunek, Jean M., Alan A. Benton, and Christopher B. Keys, "Third Party Intervention and Bargaining Behavior of Group Representatives", Journal of Conflict Resolution, 1975.

Burton, J. W., Conflict and Communication: The Use of Controlled Communication in International Relations, London: MacMillan, 1969.

Cason, John Yahya, Kamal El-Fadl and Fredrick Fareed, An Exhaustive Concordance of the Meaning of Qur'an, Baltimore, Md.: Islamic African Relief Agency, Eastern Regional Office, 2000.

Coulson, Robert, "Wipo Publication n. 728(E)".

Creighton, James L., "A Tutorial: Acting as a Conflict Conciliator", Environmental Professional, 1980.

Erickson, Randall L., "Presentation: Mediation of an Illegal Dumping Case," Annual Partnership Conference, August 21-23, 2001, online: Canadian Integrated Waste Management Board http://www.ciwmb.ca.gov.

Fisher, Ronald J., "Third Party Consultation: A Method for the Study and Resolution of Conflict", Journal of Conflict Resolution, 1972.

Folberg, Jay and Alison Taylor, Mediation: A Comprehensive Guide to Resolving Conflicts Without Litigation, San Francisco: Jossey-Bass, 1984.

Friess, John W., The Source of Power of Mediators in the Resolution of Conflict, Master Thesis, University of Wisconsin, 1986.

Lim, P.G., "Wipo Publication n. 759(E)". 
Mājah, Muhammad Ibn Yãzid al-Qazwaynīi Ibn, Sunan Ibn Mäjah, Vol. I, Cairo: 'Isāa al-Bābi al-Halābì wa Syirkah, 1952.

McAuliffe, Jane Dammen, Encyclopaedia of the Qur'an, Leiden: Brill, 2001. Mishri, 'Abd al-Rauf al-, Mu'jam al-Qur'an, Cairo: Maṭba'ah Hijāzȳy, 1948.

Noll, Douglas E. "A Theory of Mediation", Dispute Resolution Journal, 2001.

Page-Page, Richard W. \& Busch-San Diego-Cal. USA-, "The Institutional Response to Changing Needs of Users", Paper, presented to the Biennal Conference of the International Federation of Commercial Arbitration Institutions (IFCAI), hosted by the WIPO in Geneva October 24, 1997.

Pirie, Andrew J., Alternative Dispute Resolution, Skills, Science, and the Law, Toronto: Irwin Law, 2000.

Pruitt, D. G., Negotiation Behavior, New York: Academic, 1981.

Robins, Eva and Tia S. Deenenberg, A Guide for Labor Mediators, Honolulu, Hawaii: University of Hawaii, 1976.

Stevens, Carl. M., "Mediation and the Role of the Neutral" in John T. Dunlop and Neil W. Chamberlain, eds., Frontiers of Collective Bargaining, New York: Harper \& Row, 1967. 